\title{
An exploratory study on the influence of socio-demographic characteristics on water end uses inside buildings
}

\author{
Cristina Matos ${ }^{\mathrm{a}, *}$, Carlos A. Teixeira ${ }^{\mathrm{b}}$, Ricardo Bento ${ }^{\mathrm{a}, \mathrm{c}}$, João Varajão ${ }^{\mathrm{a}, \mathrm{d}}$, Isabel Bentes ${ }^{\mathrm{a}}$ \\ a ECT, University of Trás-os-Montes e Alto Douro (UTAD), Apartado 1013, 5001-801 Vila Real, Portugal \\ b CITAB, University of Trás-os-Montes e Alto Douro, Apartado 1013, 5001-801 Vila Real, Portugal \\ ' USIG, INESC TEC - INESC Technology and Science (formerly INESC Porto), Portugal \\ d Centro ALGORITMI, Portugal
}

\section{H I G H L I G H T S}

- Water end use per domestic device in three regions of Portugal.

- Evaluation of possible relations with the socio-demographic characteristics.

- The results found reflect differences in rural and urban lifestyles.

- Significant correlations were found between the water end use per domestic device and some socio-demographic characteristics.

\section{A R T I C L E I N F O}

\section{Article history}

Received 17 April 2013

Received in revised form 21 June 2013

Accepted 12 July 2013

Available online 8 August 2013

Editor: D. Barcelo

\section{Keywords:}

Socio-demographic characteristics

End use

Water

\begin{abstract}
A B S T R A C T
Any strategy of water demand management needs the collaboration of the population involved and so it is important to know how characteristics as residence area, number of residents, presence/absence of children/elders, income level, and educational level, among others, may influence the use of water. Empirical studies that quantify relationship between socio-demographic factors and the water end use patterns inside buildings are still largely lacking.

To help to fill this gap this paper gathers information about the characterization of water end use per domestic device in three regions of north of Portugal with different socio-demographic characteristics. The main research goal was to establish indoor water end use patterns per domestic device and to evaluate possible relations between these patterns with the socio-demographic characteristics of the area where the household is, namely the number of residents, the presence/absence of children/elders, the income level and educational level.

The washbasin is in average the domestic device with more number of uses in a day (responsible for $34 \%$ of the total use), close followed by the kitchen sink (32\%), the toilet flush (23\%), the bathtub (6\%) and finally the dishwasher $(3 \%)$ and the washing machine (2\%). The results found might reflect differences in rural and urban lifestyles once that, with the exception of the kitchen sink, Valpaços is the city that registers the lowest number of uses in the appliances monitored. Significant correlations were found in the following cases: between the residence area and the number of uses in washbasin and in the toilet flush; between the presence of children in the household and the use in the dishwasher; between the income level and the number of uses in the washbasin, in the bathtub, in the washing machine and in the dishwasher.
\end{abstract}

(c) 2013 Elsevier B.V. All rights reserved.

\section{Introduction}

The sustainable management of water has become a central issue to be discussed specially in countries with predicted or in water stress. Portugal has a high potential in water resources, but not all are available to use due to an unsuitable temporal and spatial distribution. Besides, Portugal is already in the rank of countries with medium water stress

\footnotetext{
* Corresponding author. Tel.: + 351 259350394; fax: + 351259350356. E-mail address: crismato@utad.pt (C. Matos).
}

(10\%-20\%) compounded by high values of water use inefficiency, mainly in agriculture but also in urban areas (Melo-Batista, 2002).

The amount of water needed for domestic consumption in developed countries, is around 100 to $180 \mathrm{l} /$ person/day, which corresponds to $30-70 \%$ of the amount of water required in an urban area (Friedler et al., 2005).

In order to achieve sustainable water demand management (WDM) that is defined as the practical "development and implementation of strategies aimed at influencing demand" (Willis et al., 2011a), it is imperative to know in detail how water is used inside buildings. 
Any strategy of water demand management has to have the collaboration of the population involved and so it is necessary to know how characteristics as residence area, number of residents, presence/absence of children/elders, income level, and educational level, among others, may influence the use of water. In fact, past research has determined that water consumption within households is dependent on numerous factors (Hadjikakou et al., 2013; Willis et al., 2011a; Tortella and Tirado, 2011; Niccolucci et al., 2011; Jorgensen et al., 2009; Inman and Jeffrey, 2006). There are socio-demographic factors namely owner occupied properties, income level of the families and household composition (presence of garden and swimming-pools) that are proved to influence water consumption (Loh and Coghlan, 2003; ARCWIS, 2002; Mayer and DeOreo, 1999).

Willis et al. (2011b), evaluated the impact of household makeup on end use water consumption and have concluded that there is a general decrease in consumption per capita as family size increases. In fact, in principle, a higher number of people living in a household lead to a better economy of scale. Arbués et al. (2003) argue that there is an optimum household size, and that beyond a specific edge these economies of scale tend to disappear.

Researchers working with domestic water consumption models have proven that, in general, higher water prices lead to lower consumption (Shaw, 2005). However, the price elasticity of water demand varies according to the use given (Reynaud, 2003). The more basic and essential is the use, the closer to zero is the price elasticity of this demand. As a result, price mechanisms would not make a great difference in the demand (Dalhuisen et al., 2003; Renwick and Green, 2000). Nauges and Thomas (2000) stated that elderly presenting lower incomes show more vulnerability to water price mechanism.

In some countries, the price of water do not seem to influence water consumption since residential water demand is largely price rigid because of its relative cost when compared to other life essentials (Worthington and Hoffman, 2008). This does not seem to be the Portuguese reality, especially in cities in the interior part of the country that register low incomes compared with the national average and where water has a very high price. For the same reasons, the income level is another factor that may have effect on water use. There is, however, some research that demonstrated this factor have a bigger influence on external uses in internal water consumption (Mayer and DeOreo, 1999). In a recent study, Willis et al. (2011b) concluded that lower income households were show to consume less water contrarily to high and middle to upper household income.

It is widely accepted that domestic water consumption is positively correlated with income (Hoffmann et al., 2006). However, if on the one hand higher levels living standards imply a higher quantity of water consuming appliances and the presence of high water demanding external uses (Cole, 2004; Domene et al., 2005), on the other hand, income affects significantly on the responsiveness to price mechanism. In other words, while low income families may not respond to price because they are using water only for basic needs, high income families fill to respond to the price signal, once it is not strong enough to reduce their consumption (Corbella and Pujol, 2009).

Gregory and Di Leo (2003) researched and found that in past findings, higher income families tended to be more involved in pro-environmental activities, had greater concern for the environment and participated to a greater extent in conservation activities that lower income families did. However, their results in 2003 indicated that households with greater awareness and involvement in the decision to use water were older, had lower income and educational levels, and had fewer people living in the household.

Gilg and Barr (2006) carried out a study and the results showed that aged individuals, who own their home, with democratic and liberal political ideas and who are members of community groups, are more committed with water efficient use. This contrasts with non-ecological individuals who tend to be young men, with low incomes and a low level of education, who are less involved with the community and politically apathetic (Mondéjar-Jiménez et al., 2010).

The educational level may also have impact on water use since the water use patterns highly depend on the consideration of sustainable water consumption practices, and on the understanding of its importance to environment itself (Hassell and Cary, 2007). Furthermore, environmental behaviour is also affected by situational influences like the educational level (Jorgensen et al., 2009).

Previous water consumption investigation indicates that persons that are wealthier, older and live in new and larger households consume more (Kim et al., 2007; Kenney et al., 2008). Willis et al. (2011b) determined that the location of household, lot size, rain water tank ownership, household income and household makeup do influence end use water consumption (Willis et al., 2011c). In respect with the socioeconomic region of households Willis et al. (2011b), selected and compared four socio-economic groups in distinct regions, and found out that the middle to high group was the one that registered the highest total per capita consumption. However, in this study it was not possible to know for certain which end uses are potentially affected by the socioeconomic region. Generally these investigators concluded that lower socio-economic groups tended to slightly use more water inside buildings than those in higher socio-economic groups transversely most end uses categories.

Murdock et al. (1991), defended that the age structure of a given population is a relevant driver of domestic water consumption. Older people may show more saving attitudes and the young might use water less carefully, have more showers and demand more frequent laundering (Nauges and Thomas, 2000).

These works presented important results, however empirical studies that quantify relationship between socio-demographic factors and the water end use patterns inside buildings are still largely lacking within the current body of knowledge.

To help to fill this gap this paper gathers information about the characterization of water end use per domestic device in three regions of north Portugal that have significant differences considering socio-demographic characteristics. This was established by a case study using a representative sample of the local community. The main research goal was to establish indoor water use patterns per domestic device and to relate these patterns with the socio-demographic characteristics of the area where the household is, namely the number of residents, the presence/absence of children/elders, the income level and educational level.

\subsection{Case study}

\subsubsection{Geographical and socio-demographic framework}

The study was developed in three Portuguese municipalities each with one representative of a distinct level of the Northern regional urban system, with different classifications in terms of Eurostat's urban-rural typology (Fig. 1), and with some significant demographic and socioeconomic differences (Fig. 2).

Oporto, with a population of 237,591 inhabitants, is the core of the country's second biggest metropolitan area and plays the role of regional capital of the North region of Portugal. It has a relatively old age structure (presenting an ageing index of $194^{1}$ ) and in terms of employment is heavily dependent of the tertiary economic sector. Its resident population presents a relatively high level of educational attainment (23\% of population with tertiary education) and has a

\footnotetext{
${ }^{1}$ Ageing index $=[$ (number of people aged 65 and over) / (number of people aged $0-14)] \times 100$.
} 


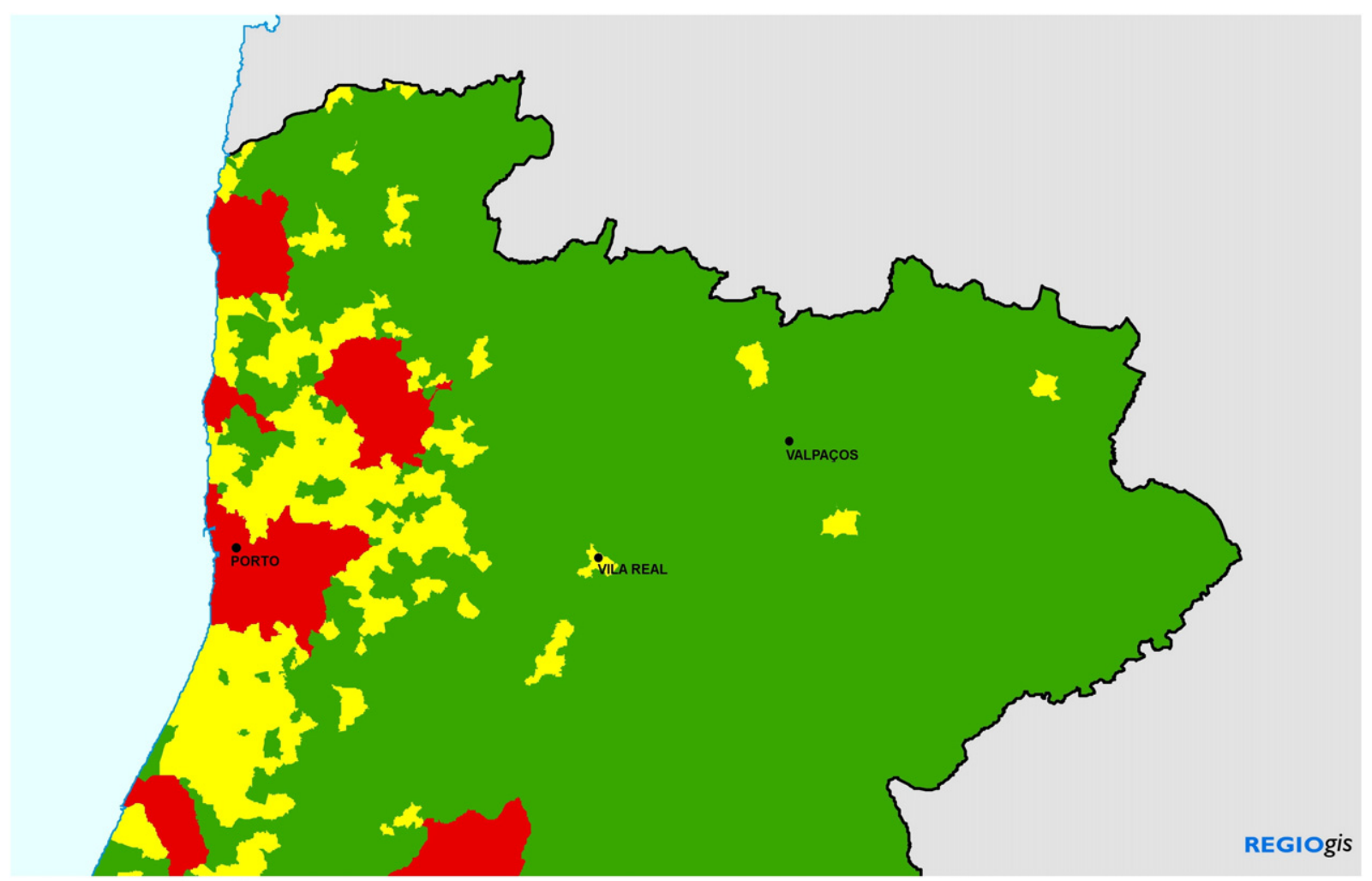

\section{Degree of Urbanization 2011}

Densely populated area

Intermediate

Thinly populated area

No Data

Sources: EFGS, JRC, Eurostat, LandScan, REGIO-GIS

( EuroGeographics Association for the administrative boundaries

Fig. 1. Research geographic area in the north of Portugal (EFGS, JCR, Eurostat, LanScan, REGIO-GIS, 2013).

high average monthly earning (almost 1.2 times higher than the national average) (Fig. 2).

Vila Real is a medium sized municipality integrated in the Douro Valley area of the Interior North region and plays an important role in the regional urban system equilibrium. It has a population of 51,850 inhabitants, presenting a relatively young age structure (ageing index of 121 ) and a medium level of educational attainment ( $17 \%$ of population with tertiary education). It also presents a heavily tertiary economy (almost $80 \%$ of the employed population works in this activity sector), but with a relatively low average monthly earning ( $85 \%$ of the national average).

Valpaços is a small municipality with 16,882 inhabitants, located in the border region in the Interior of the North region. It presents a very elderly population structure (ageing index of 313) and a low level of educational attainment, with more than $60 \%$ of the resident population only completed the primary level. It has a low average monthly earning level (only $67 \%$ of the national average) which is clearly related with the strong economic dependency of the primary and secondary sectors, since $42 \%$ of the resident population works in agriculture and agro industrial sector.

Considering the demographic differences it is important and particularly interesting to study the relationship between occupant's characteristics (age, income level, educational level, among others) and habits regarding the water end-uses distribution.

\section{Methods}

\subsection{Water end-use monitoring}

Determination of water use within a household requires specific knowledge on how, where, when and who consumes water. To determine these elements, a previous study (Matos et al., 2013) distributed a survey to 36 different dwellings within Valpaços (11), Vila Real (13) and Oporto (12), the three Portugal regions on which the case study was focused. The total number of participants was 109 . To assure the representativeness of the results, the adopted sampling method was the stratified random method. Stratification is the process of dividing the population into homogeneous subgroups or strata before sampling. Then, the participant subjects are randomly selected proportionally from the different strata. This enables to improve the representativeness of the sample by reducing sampling error.

It was asked to the households to record data every time a single device was used (each time the tap/flush was switched-on) during a week (seven days) in March of 2011. In the washbasin, the bathtub and in the kitchen sink, there was a record of the type of use, namely in the washing basin the uses "washing teeth", "shave", "washing hands" and "washing face", in the bathtub "bath" or "shower" and in the kitchen sink the uses "washing dishes", "washing hands", "drink water", "washing vegetables" and "washing fruits". 
Population by age group (2011)

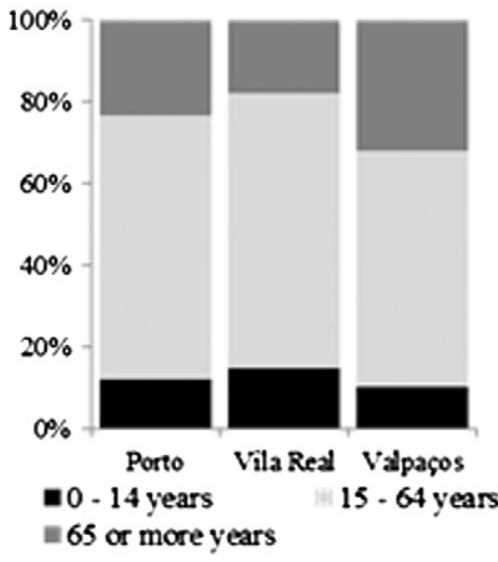

Employed Population by economic activity sector (2011)

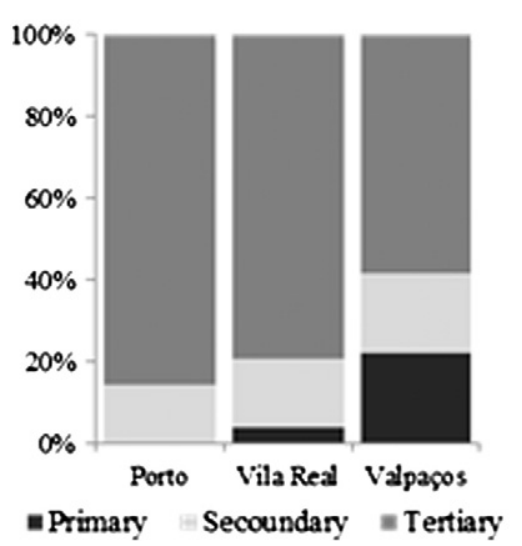

Population by educational attainment level (2011)

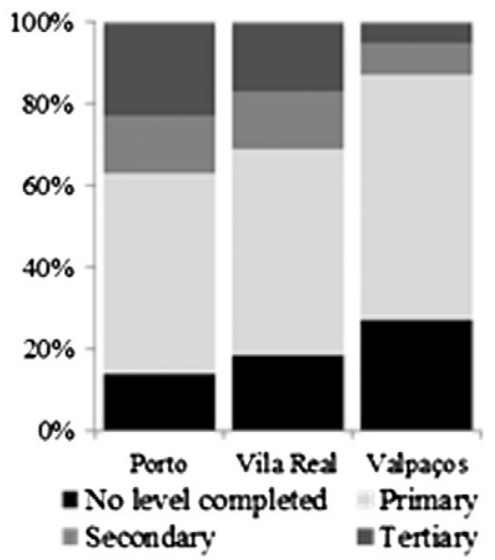

Average monthly earning (2009)

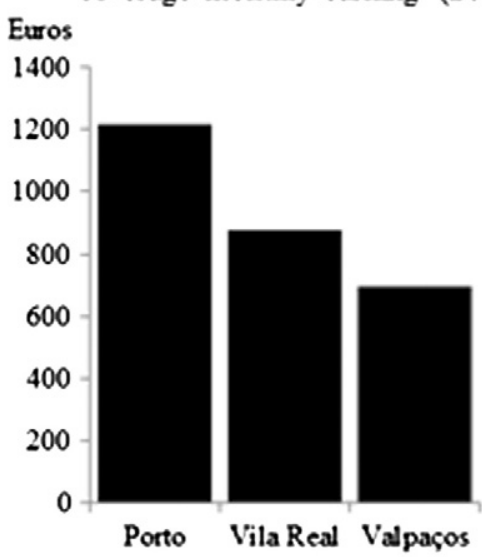

Fig. 2. Demographic and socio-economic indicators of the case study municipalities.

In the same survey biographical data was also gathered: residence area, characterization of household (the number of persons living in; the presence/absence of children and the presence/absence of elders), the income level; and the educational level.

\subsection{Data analysis}

Data obtained from the survey was compiled into IBM SPSS version 20.0 for the purpose of statistical analysis. Based on the data obtained from the 36 survey respondents, descriptive statistical analysis was first performed on the variables being studied to examine the respective means and frequencies.

The reliability of the measurement tool was evaluated. According to Forza (Forza, 2002), reliability indicates dependability, stability, predictability, consistency and accuracy, and refers to the extent to which a measuring procedure yields the same results in repeated trials. Reliability can be assessed in four different ways: test-related method; alternative form method; split halves method; and internal consistency method. This study used an internal consistency method by calculating Cronbach's Alpha, which is the most popular test for internal consistency (Ferreira and Laurindo, 2009).

The result of the internal consistency test of the variables calculated using SPSS $®$ was 0.697. According to Nunnally (1978) and Forza (2002), since Alpha is greater than 0.6 and in the 0.7 level, the measurement instrument used in this study can be accepted. After confirming the reliability of the measurement instrument we proceeded to the analysis of the data.

Further, aiming to identify the influence of socio-demographic characteristics on water end uses inside buildings, it was done with a correlation analysis using the Spearman's correlation test. For each significant correlation found, it was then created a crosstab considering the involved variables to enable a better understanding of the correlation.

The Spearman rank-order correlation coefficient (Spearman's correlation), is a non-parametric measure of the strength and direction of association that exists between two variables measured on at least an ordinal scale. In other words, is a nonparametric measure of statistical dependence between two variables.

The obtained results are present and discussed in the next section.

\section{Results and discussion}

\subsection{Water end-use characterization}

As referred by Matos et al. (2013) the washbasin is, in average, the domestic device with more number of uses per capita in a day (responsible for 4.0 uses per day $/ 34 \%$ of the total use), close followed by the kitchen sink (3.7 uses per day/32\%), the toilet flush ( 2.7 uses per day/23\%), the bathtub (0.7 uses per day/6\%) and finally the dishwasher ( 0.3 uses per day/3\%) and the washing machine (0.3 uses per day/2\%) (Matos et al., 2013). The oddest value is the one presented on the bathtub, once it 
indicates that volunteers, in average, do not have a bath per day, what is strange in a Mediterranean country. In fact comparing these results with the ones found by Ghisi \& Oliveira, in 2007 it is notice that in Brazil the frequency found is bigger (1.09-1.58 times a day). In the hand washbasin, the results fall within the results presented by Ghisi \& Oliveira (3.22-8.75 times a day), on the contrary to what happens in toilet flush that the ones presented in this study are lower than the ones presented by the referenced study (3.21-6.32 times a day).

Comparing these results with the ones found by Ghisi and Oliveira (2007) to the washing machine (0.30-0.36 times a day) and to the kitchen sink (2.68-2.09 times a day) they are not significantly different, however the biggest difference is in the kitchen sink, maybe because the major part of the occupants in the present study do make their two biggest (lunch and dinner) meals at home. The uses regarding the machines reveal that the volunteers do not switch them on every day.

With the exception of the kitchen sink, Valpaços is the city that registers the lowest number of uses in the appliances monitored. Vila Real and Oporto have similar results with the exception of the kitchen sink, where Vila Real is the city with the largest number of uses. This may reflect some of the population habits, namely the fact that the occupants do their meals at home. Oporto is a big city and so it is sometimes difficult to have lunch at home. These results might reflect differences in rural and urban lifestyles (Matos et al., 2013).

\subsection{Data analysis results}

As referred in methods section, there were performed statistical correlation tests aiming to find correlations between the following independent variables: Residence area, number of residents, presence of children, presence of elders, income level and educational level, and the following dependent variables: number of uses per capita per week of the bidet, of the washbasin, of the toilet flush, of the bathtub, of the kitchen sink, of the washing machine and of the dishwasher.

Fig. 3 summarises the significant correlations that were found. In what concerns to the "number of residents", "presence of elders" and "level of education", there was not found any significant correlation between these and the number of uses in the various sanitary appliances.

Significant correlations were found considering the residence area and the numbers of uses in washbasin and in the toilet flush.

Residents from Valpaços less use the washbasin and toilet flush than the ones from Oporto and Vila Real (Tables 1 and 2). These may due to several factors related to residents' habits and lifestyles such as hygienic habits and water cost concerns. Actually, Gregory and Di Leo (2003) in their study argued that older people that grew up in rural and semirural areas consume less water because awareness about water scarcity and the need to save water from tanks and reservoirs was a part of their routine. As already referenced before, Willis et al. (2011b) suggested that regions with middle to high socio-economic conditions, that will be the case of Vila Real and Oporto, normally register the highest total per capita consumption. However, in this research, Willis et al. (2011b) were not able to recognise which end uses are possibly more influenced by socio-economic region.

Significant correlations (Fig. 3) were found between the presence of children in the household and the use in the dishwasher. This correlation may be explained by the fact that those who have children naturally uses the dishwasher more (Table 3), once the use of dishes in the presence of children is higher.

In the few studies that do exist on this matter, it seems that older people tend to spend less water per capita than the young. Moreover, families with children and teenagers can be expected to use more water, but mainly in external uses (Corbella and Pujol, 2009).

Nauges and Thomas (2000), in their study conducted in eastern France, found that residential areas with a higher proportion of a young

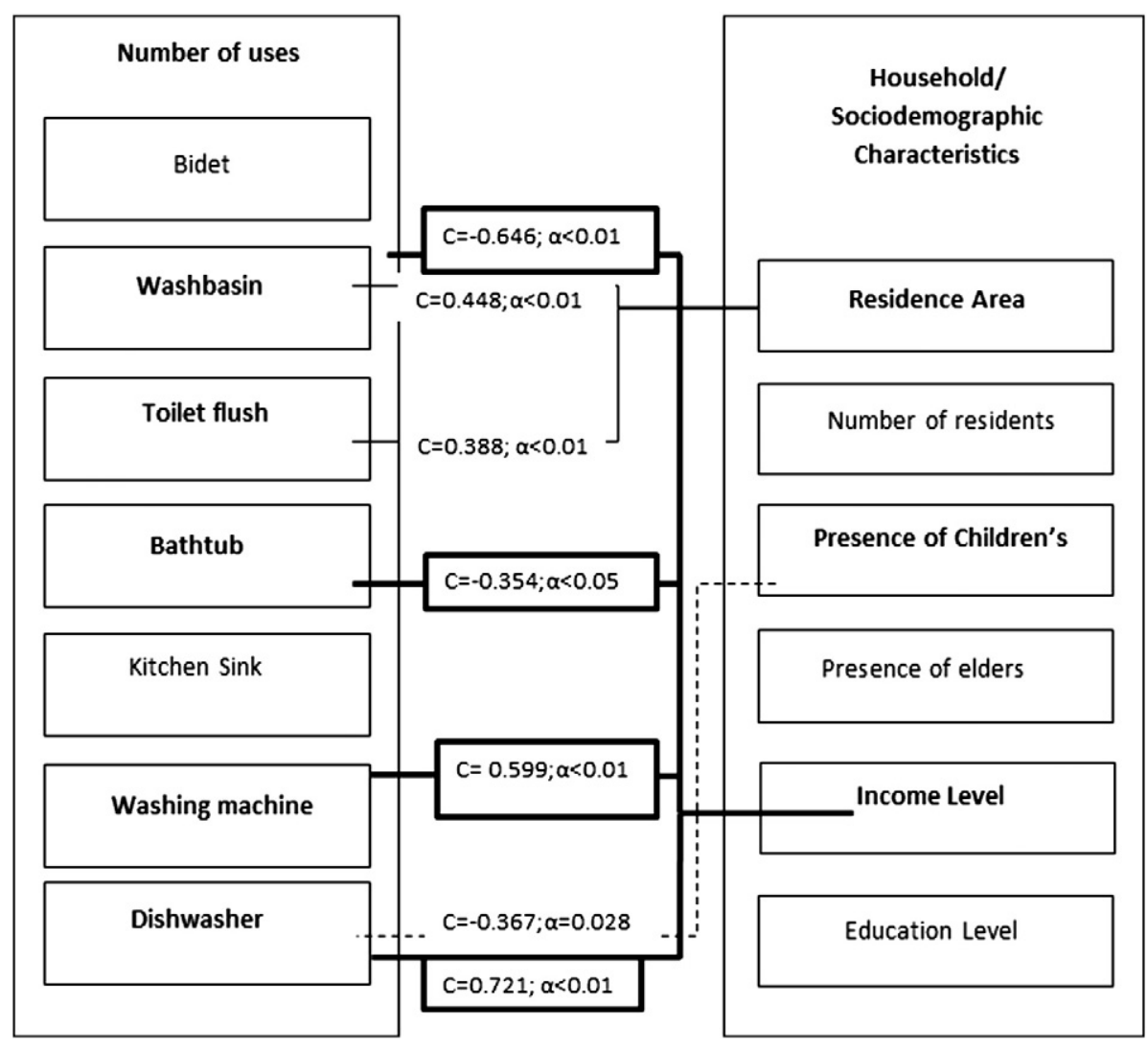

Fig. 3. Correlations found ( $\mathrm{C}=$ correlation coefficient; $\alpha=$ correlation significance). 
Table 1

Number of uses of the washbasin, per residence area.

\begin{tabular}{|c|c|c|c|c|}
\hline & & \multicolumn{3}{|c|}{$\begin{array}{l}\text { Uses in the washbasin per capita } \\
\text { per week }\end{array}$} \\
\hline & & $\begin{array}{l}\text { Less than } 35 \text { uses } \\
\text { per capita per week }\end{array}$ & $\begin{array}{l}35 \text { uses or } \\
\text { more }\end{array}$ & Total \\
\hline \multirow[t]{4}{*}{ Valpaços } & Count & 10 & 1 & 11 \\
\hline & $\%$ within residence area & 90.9 & 9.1 & 100.0 \\
\hline & $\begin{array}{l}\% \text { within uses in the washbasin } \\
\text { per capita per week }\end{array}$ & 55.6 & 5.6 & 30.6 \\
\hline & $\%$ of total & 27.8 & 2.8 & 30.6 \\
\hline \multirow[t]{4}{*}{ Vila Real } & Count & 4 & 9 & 13 \\
\hline & $\%$ within residence area & 30.8 & 69.2 & 100.0 \\
\hline & $\begin{array}{l}\% \text { within uses in the washbasin } \\
\text { per capita per week }\end{array}$ & 22.2 & 50.0 & 36.1 \\
\hline & $\%$ of total & 11.1 & 25.0 & 36.1 \\
\hline \multirow[t]{4}{*}{ Oporto } & Count & 4 & 8 & 12 \\
\hline & $\%$ within residence area & 33.3 & 66.7 & 100.0 \\
\hline & $\begin{array}{l}\% \text { within uses in the washbasin } \\
\text { per capita per week }\end{array}$ & 22.2 & 44.4 & 33.3 \\
\hline & $\%$ of total & 11.1 & 22.2 & 33.3 \\
\hline \multirow[t]{4}{*}{ Total } & Count & 18 & 18 & 36 \\
\hline & $\%$ within residence area & 50.0 & 50.0 & 100.0 \\
\hline & $\begin{array}{l}\% \text { within uses in the washbasin } \\
\text { per capita per week }\end{array}$ & 100.0 & 100.0 & 100.0 \\
\hline & $\%$ of total & 50.0 & 50.0 & 100.0 \\
\hline
\end{tabular}

population are likely to be greater water consumers due to a higher frequency of laundering and outdoor water use for recreational purposes. The opposite behaviour occurs in the case of residential developments designed predominantly for an elderly population, whom the authors identified as much cautious water consumers. Similar results were shown by Martínez-Espiñeira (2003) in Galicia (Spain), who concluded that the residential population over 64 years of age had a more serious water consumption compared with the younger population. In contrast, municipalities with a higher proportion of the population less than 19 years old observed higher domestic water consumption.

However, Lyman (1992), showed that older people tend to spend more time at home by which may lead to greater water consumption.

The income level is significantly correlated with the number of uses in the washbasin (Fig. 3), in the bathtub, in the washing machine and in the dishwasher. Relatively to the washbasin the lowest class $(<500 €)$ is the one that uses this device more for both frequencies studied, appositively

Table 2

Number of uses of the toilet flush per residence area.

\begin{tabular}{|c|c|c|c|c|}
\hline & & \multicolumn{2}{|c|}{$\begin{array}{l}\text { Uses of the toilet flush per } \\
\text { capita per week }\end{array}$} & \multirow[t]{2}{*}{ Total } \\
\hline & & $\begin{array}{l}\text { Less than } 20 \text { uses per } \\
\text { capita per week }\end{array}$ & $\begin{array}{l}20 \text { uses } \\
\text { or more }\end{array}$ & \\
\hline \multirow[t]{4}{*}{ Valpaços } & Count & 9 & 2 & 11 \\
\hline & $\%$ within residence area & 81,8 & 18,2 & 100,0 \\
\hline & $\begin{array}{l}\% \text { within uses in the toilet flush } \\
\text { per capita per week }\end{array}$ & 45,0 & 12,5 & 30,6 \\
\hline & $\%$ of total & 25,0 & 5,6 & 30,6 \\
\hline \multirow[t]{4}{*}{ Vila Real } & Count & 7 & 6 & 13 \\
\hline & $\%$ within residence area & 53.8 & 46.2 & 100.0 \\
\hline & $\begin{array}{l}\% \text { within uses in the toilet flush } \\
\text { per capita per week }\end{array}$ & 35.0 & 37.5 & 36.1 \\
\hline & $\%$ of total & 19.4 & 16.7 & 36.1 \\
\hline \multirow[t]{4}{*}{ Porto } & Count & 4 & 8 & 12 \\
\hline & $\%$ within residence area & 33.3 & 66.7 & 100.0 \\
\hline & $\begin{array}{l}\% \text { within uses in the toilet flush } \\
\text { per capita per week }\end{array}$ & 20.0 & 50.0 & 33.3 \\
\hline & $\%$ of total & 11.1 & 22.2 & 33.3 \\
\hline \multirow[t]{4}{*}{ Total } & Count & 20 & 16 & 36 \\
\hline & $\%$ within residence area & 55.6 & 44.4 & 100.0 \\
\hline & $\begin{array}{l}\% \text { within uses in the toilet flush } \\
\text { per capita per week }\end{array}$ & 100.0 & 100.0 & 100.0 \\
\hline & $\%$ of total & 55.6 & 44.4 & 100.0 \\
\hline
\end{tabular}

Table 3

Number of uses of the dishwasher according with the presence of children.

\begin{tabular}{|c|c|c|c|c|}
\hline & & \multicolumn{2}{|c|}{$\begin{array}{l}\text { Uses of the } \\
\text { dishwasher per } \\
\text { capita per week }\end{array}$} & \multirow[t]{2}{*}{ Total } \\
\hline & & 0 & More than 0 & \\
\hline \multirow[t]{4}{*}{ Presence of children } & Count & 1 & 4 & 5 \\
\hline & \% within children & 20.0 & 80.0 & 100.0 \\
\hline & $\begin{array}{l}\% \text { within uses in the dishwasher } \\
\text { per capita per week }\end{array}$ & 4.3 & 30.8 & 13.9 \\
\hline & $\%$ of total & 2.8 & 11.1 & 13.9 \\
\hline \multirow[t]{4}{*}{ Absence of children } & Count & 22 & 9 & 31 \\
\hline & $\%$ within children & 71.0 & 29.0 & 100.0 \\
\hline & $\begin{array}{l}\% \text { within uses in the dishwasher } \\
\text { per capita per week }\end{array}$ & 95.7 & 69.2 & 86.1 \\
\hline & $\%$ of total & 61.1 & 25.0 & 86.1 \\
\hline \multirow[t]{4}{*}{ Total } & Count & 23 & 13 & 36 \\
\hline & $\%$ within children & 63.9 & 36.1 & 100.0 \\
\hline & $\begin{array}{l}\% \text { within uses in the dishwasher } \\
\text { per capita per week }\end{array}$ & 100.0 & 100.0 & 100.0 \\
\hline & $\%$ of total & 63.9 & 36.1 & 100.0 \\
\hline
\end{tabular}

to the medium class of income (500-1500 $€$ ) that uses much less the washbasin. Unexpectedly in the highest class of income $(>1500 €)$ that all the participants use the washbasin no more than 35 times per capita per week (Table 4). Regarding the use of the bathtub is the lowest class income that registers more uses for frequencies studied (Table 5). The distribution of uses, in the washing machine, reveals that people that earn more, use this device more often (Table 6).

Income can have a positive indirect effect on water savings as a result of its relationship with education. Flack and Greenberg (1987) studied the attitudes of residents toward water conservation in 7 cities in the state of Colorado (USA), finding that the likelihood of installing mechanisms to conserve water for toilets and showers increased with income and educational level. Berk et al. (1993), in the case of the Los Angeles area and the Bay Area of San Francisco, also showed that there was a positive relationship between income and water conservation behaviours.

In the dishwasher, the distribution of uses reveals that medium class uses more this device than the higher class (Table 7). This may related to the fact that people with this level of income make more meals out at

Table 4

Number of uses of the washbasin according with the income.

\begin{tabular}{|c|c|c|c|c|}
\hline & & \multicolumn{2}{|c|}{$\begin{array}{l}\text { Uses in the washbasin } \\
\text { per capita per week }\end{array}$} & \multirow[t]{2}{*}{ Total } \\
\hline & & $\begin{array}{l}\text { Less than } 35 \\
\text { uses per capita } \\
\text { per week }\end{array}$ & $\begin{array}{l}35 \text { uses or } \\
\text { more }\end{array}$ & \\
\hline \multirow[t]{4}{*}{$<500 €$} & Count & 3 & 14 & 17 \\
\hline & $\%$ within Income & 17.6 & 82.4 & 100.0 \\
\hline & $\begin{array}{l}\% \text { within uses in the washbasin } \\
\text { per capita per week }\end{array}$ & 16.7 & 77.8 & 47.2 \\
\hline & $\%$ of total & 8.3 & 38.9 & 47.2 \\
\hline \multirow{4}{*}{$\begin{array}{l}\geq 500 € \\
\quad \text { to } \leq 1500 €\end{array}$} & Count & 9 & 4 & 13 \\
\hline & $\%$ within Income & 69.2 & 30.8 & 100.0 \\
\hline & $\begin{array}{l}\% \text { within uses in the washbasin } \\
\text { per capita per week }\end{array}$ & 50.0 & 22.2 & 36.1 \\
\hline & $\%$ of total & 25.0 & 11.1 & 36.1 \\
\hline \multirow[t]{4}{*}{$>1500 €$} & Count & 6 & 0 & 6 \\
\hline & $\%$ within Income & 100.0 & 0.0 & 100.0 \\
\hline & $\begin{array}{l}\% \text { within uses in the washbasin } \\
\text { per capita per week }\end{array}$ & 33.3 & 0.0 & 16.7 \\
\hline & $\%$ of total & 16.7 & 0.0 & 16.7 \\
\hline \multirow[t]{4}{*}{ Total } & Count & 18 & 18 & 36 \\
\hline & $\%$ within Income & 50.0 & $50.0 \%$ & 100.0 \\
\hline & $\begin{array}{l}\% \text { within uses in the washbasin } \\
\text { per capita per week }\end{array}$ & 100.0 & $100.0 \%$ & 100.0 \\
\hline & $\%$ of total & 50.0 & $50.0 \%$ & 100.0 \\
\hline
\end{tabular}


Table 5

Number of uses of the bathtub according with the income.

\begin{tabular}{|c|c|c|c|c|}
\hline & & \multicolumn{2}{|c|}{$\begin{array}{l}\text { Uses of the bathtub per } \\
\text { capita per week }\end{array}$} & \multirow[t]{2}{*}{ Total } \\
\hline & & $\begin{array}{l}\text { Less than } 5 \text { uses } \\
\text { per capita per } \\
\text { week }\end{array}$ & $\begin{array}{l}5 \text { or more } \\
\text { uses }\end{array}$ & \\
\hline \multirow[t]{4}{*}{$<500 €$} & Count & 5 & 12 & 17 \\
\hline & $\%$ within Income & 29.4 & 70.6 & 100.0 \\
\hline & $\begin{array}{l}\% \text { within uses in the bathtub } \\
\text { per capita per week }\end{array}$ & 31.2 & 60.0 & 47.2 \\
\hline & $\%$ of total & 13.9 & 33.3 & 47.2 \\
\hline \multirow{4}{*}{$\begin{array}{l}\geq 500 € \\
\quad \text { to } \leq 1500 €\end{array}$} & Count & 6 & 7 & 13 \\
\hline & $\%$ within Income & 46.2 & 53.8 & 100.0 \\
\hline & $\begin{array}{l}\% \text { within uses in the bathtub } \\
\text { per capita per week }\end{array}$ & 37.5 & 35.0 & 36.1 \\
\hline & $\%$ of total & 16.7 & 19.4 & 36.1 \\
\hline \multirow[t]{4}{*}{$>1500 €$} & Count & 5 & 1 & 6 \\
\hline & $\%$ within Income & 83.3 & 16.7 & 100.0 \\
\hline & $\begin{array}{l}\% \text { within uses in the bathtub } \\
\text { per capita per week }\end{array}$ & 31.2 & 5.0 & 16.7 \\
\hline & $\%$ of total & 13.9 & 2.8 & 16.7 \\
\hline \multirow[t]{4}{*}{ Total } & Count & 16 & 20 & 36 \\
\hline & $\%$ within Income & 44.4 & 55.6 & 100.0 \\
\hline & $\begin{array}{l}\% \text { within uses in the bathtub } \\
\text { per capita per week }\end{array}$ & 100.0 & 100.0 & 100.0 \\
\hline & $\%$ of total & 44.4 & 55.6 & 100.0 \\
\hline
\end{tabular}

restaurants. The lowest class income does not use the dishwasher, maybe because they do not have it, or maybe because it is too expensive to use it.

The demand of many consumer goods, such as water, tends to increase proportionally with the income of households, once the water bill represents a very small portion of the family budget (Hoffmann et al., 2006). Higher levels of living standards imply a higher quantity of water consuming appliances and the presence of high water demanding external uses (Cole, 2004; Domene et al., 2005).

Table 6

Number of the washing machine, according with the income.

\begin{tabular}{|c|c|c|c|c|c|}
\hline & & \multicolumn{3}{|c|}{$\begin{array}{l}\text { Uses of the washing machine per } \\
\text { capita per week }\end{array}$} & \multirow[t]{2}{*}{ Total } \\
\hline & & 0 & $\begin{array}{l}1 \text { or } 2 \text { uses } \\
\text { per capita } \\
\text { per week }\end{array}$ & $\begin{array}{l}\text { More than } 2 \\
\text { uses per capita } \\
\text { per week }\end{array}$ & \\
\hline \multirow[t]{4}{*}{$<500 €$} & Count & 12 & 3 & 2 & 17 \\
\hline & $\%$ within Income & 70,6 & 17.6 & 11.8 & 100.0 \\
\hline & $\begin{array}{l}\% \text { within uses in the } \\
\text { washing machine per } \\
\text { capita per week }\end{array}$ & 100,0 & 20.0 & 22.2 & 47.2 \\
\hline & $\%$ of total & 33,3 & 8.3 & 5.6 & 47.2 \\
\hline \multirow{4}{*}{$\begin{array}{l}\geq 500 € \\
\quad \text { to } \leq 1500 €\end{array}$} & Count & 0 & 8 & 5 & 13 \\
\hline & $\%$ within Income & 0,0 & 61.5 & 38.5 & 100.0 \\
\hline & $\begin{array}{l}\% \text { within uses in the } \\
\text { washing machine per } \\
\text { capita per week }\end{array}$ & 0,0 & 53.3 & 55.6 & 36.1 \\
\hline & $\%$ of total & 0,0 & 22.2 & 13.9 & 36.1 \\
\hline \multirow[t]{4}{*}{$>1500 €$} & Count & 0 & 4 & 2 & 6 \\
\hline & $\%$ within Income & 0,0 & 66.7 & 33.3 & 100.0 \\
\hline & $\begin{array}{l}\% \text { within uses in the } \\
\text { washing machine per } \\
\text { capita per week }\end{array}$ & 0,0 & 26.7 & 22.2 & 16.7 \\
\hline & $\%$ of total & 0,0 & 11.1 & 5.6 & 16.7 \\
\hline \multirow[t]{4}{*}{ Total } & Count & 12 & 15 & 9 & 36 \\
\hline & $\%$ within Income & 33,3 & 41.7 & 25.0 & 100.0 \\
\hline & $\begin{array}{l}\% \text { within uses in the } \\
\text { washing machine per } \\
\text { capita per week }\end{array}$ & 100,0 & 100.0 & 100.0 & 100.0 \\
\hline & $\%$ of total & 33,3 & 41.7 & 25.0 & 100.0 \\
\hline
\end{tabular}

Table 7

Number of uses of the dishwasher, according with the income.

\begin{tabular}{|c|c|c|c|c|}
\hline & & \multicolumn{2}{|c|}{$\begin{array}{l}\text { Uses of the } \\
\text { dishwasher per } \\
\text { capita per week }\end{array}$} & \multirow[t]{2}{*}{ Total } \\
\hline & & 0 & More than 0 & \\
\hline \multirow[t]{4}{*}{$<500 €$} & Count & 17 & 0 & 17 \\
\hline & $\%$ within Income & 100.0 & 0.0 & 100.0 \\
\hline & $\begin{array}{l}\% \text { within uses in the dishwasher } \\
\text { per capita per week }\end{array}$ & 73.9 & 0.0 & 47.2 \\
\hline & $\%$ of total & 47.2 & 0.0 & 47.2 \\
\hline \multirow[t]{4}{*}{$\geq 500 €$ to $\leq 1500 €$} & Count & 5 & 8 & 13 \\
\hline & $\%$ within Income & 38.5 & 61.5 & 100.0 \\
\hline & $\begin{array}{l}\% \text { within uses in the dishwasher } \\
\text { per capita per week }\end{array}$ & 21.7 & 61.5 & 36.1 \\
\hline & $\%$ of total & 13.9 & 22.2 & 36.1 \\
\hline \multirow[t]{4}{*}{$>1500 €$} & Count & 1 & 5 & 6 \\
\hline & $\%$ within Income & 16.7 & 83.3 & 100.0 \\
\hline & $\begin{array}{l}\% \text { within uses in the dishwasher } \\
\text { per capita per week }\end{array}$ & 4.3 & 38.5 & 16.7 \\
\hline & $\%$ of total & 2.8 & 13.9 & 16.7 \\
\hline \multirow[t]{4}{*}{ Total } & Count & 23 & 13 & 36 \\
\hline & $\%$ within Income & 63.9 & 36.1 & 100.0 \\
\hline & $\begin{array}{l}\% \text { within uses in the dishwasher } \\
\text { per capita per week }\end{array}$ & 100.0 & 100.0 & 100.0 \\
\hline & $\%$ of total & 63.9 & 36.1 & 100.0 \\
\hline
\end{tabular}

Willis et al. (2011b) registered that as income increases, water consumption increases too. In the same study it is stated that lower sociodemographic profiles use more water for end uses other than irrigation.

Therefore, it is important to know the real magnitude of the effect of income on water consumption (Arbués et al., 2003; Chicoine and Ramamurthy, 1986).

Gregory and Di Leo (2003) indicated that households with greater awareness and involvement in the decision to use water were older, had lower income and educational levels, and had fewer people living in the household.

Contrarily to what was found in similar studies, which stated that the number of people living in a household influences water consumption (Zhang and Brown, 2005; Arbués et al., 2003), in the present research was not found a significant correlation between the number of residents and the number of water end uses. Willis et al. (2011b) found out that clothes washer and toilet end use consumption increase with the number of occupants in the household. This was attributed to the fact that larger families, having very young children, require extensive washing and a higher utilisation of the toilet due to increased time spent at home.

Although in this study there was no correlation found between educational level and water end uses, it is argued within the scientific community that education is related to environmental consciousness and awareness (Syme et al., 2000), and so it could be expected that people with a high educational level consume less water. However, few studies deal with the influence of people's education in water use (Howarth and Butler, 2004).

Gregory's and Di Leo's (2003) found that pro-conservationists are younger and more highly educated than are non-conservationists.

\section{Conclusion}

Despite the potentially beneficial effects of consumer's participation in the assessment of the real end use of water, there are some limitations of survey research already noted by Bruvold (1977). One of the most important are the effects of confounding variables, and so, these results must be analysed considering these types of limitations. However, as already discussed, the present research gives an important contribution to the understanding of the effects of some socio-demographic variables on the water end use pattern. This knowledge is important when seeking, for example, in situ water reuse. 
The results found might reflect differences in rural and urban lifestyles once that, with the exception of the kitchen sink, Valpaços is the city that registers the lowest number of uses in the appliances monitored. This may be justified by the finding of a similar study that stated that older people that grew up in rural and semi-rural areas consume less water because awareness about water scarcity and the need to save water from tanks and reservoirs was a part of their routine.

Significant correlations were found between the residence area and the number of uses in washbasin and in the toilet flush, resulting that lower population density areas use less often these domestic devices; between the presence of children in the household and the use in the washbasin and dishwasher. The presence of children seems to encourage the use of dishwashers; between the income level and the number of uses in the washbasin, in the bathtub, in the washing machine, and in the dishwasher. There was a trend for higher intakes associated with the middle class. This led us to advise that possible awareness campaigns should focus mainly on this class.

Although the important contribution of the results presented in the paper, correlations discussed in this paper, could be subject of further research to find other factors that might be important as well, like the permanence of the inhabitants in the household. It could be important, for instance to analyse if household price responsiveness may vary seasonally, increasing the responsiveness during summertime, including in the research the external end-uses, which were not evaluated in the present research. Another important question to be answered is if water conservation is more likely when individuals believe that water is scarce or when they perceive that other consumers are also conserving water.

\section{Conflict of interest}

For all intents and purposes the authors state that there are no any actual or potential conflict of interest including any financial, personal or other relationships with other people or organisations within three years of beginning the submitted work that could inappropriately influence, or be perceived to influence, their work.

\section{Appendix A. Supplementary data}

Supplementary data to this article can be found online at http://dx.doi. org/10.1016/j.scitotenv.2013.07.036.

\section{References}

Arbués F, García-Valiñas MA, Martínez-Espiñeira R. Estimation of residential water demand: a state-of-the-art review. J Socio-Econ 2003;32:81-102.

ARCWIS. Perth domestic water e use study household ownership and community attitudinal analysis. NWS. Australian Research Centre for Water in Society (ARCWIS) CSIRO Land and Water; 2002.

Berk RA, Schulman D, McKeever M, Freeman HE. Measuring the impact of water conservation campaigns in California. Clim Change 1993;24:233-48.

Bruvold WH. Consumer attitudes toward taste and odor in water. Journal AWWA 1977: 562.

Chicoine D, Ramamurthy G. Evidence on the specification of price in the study of domestic water demand. Land Econ 1986;62:26-32.

Cole MA. Economic growth and water use. Appl Econ Lett 2004;11:1-4.

Corbella HM, Pujol DS. What lies behind domestic water use? A review essay on the drivers of domestic water consumption. Bol Asoc Geogr Esp 2009;50:297-314.

Dalhuisen JM, Florax RGMJ, De Grooth LF, Nijkamp P. Price and income elasticities of residential water demand: a meta-analysis. Land Econ 2003;79:292-308.

Domene E, Saurí D, Pares M. Urbanization and sustainable resource use: the case of garden watering in the Metropolitan Region of Barcelona. Urban Geogr 2005;26:520-35.

EFGS, JCR, Eurostat, LanScan, REGIO-GIS, 2013.

Ferreira AMD, Laurindo FJB. Outsourcing decision-making aspects considered by IT departments in Brazilian companies. Int J Prod Econ 2009;122(1):305-11.
Flack JE, Greenberg J. Public attitudes toward water conservation. J Am Water Works Assoc 1987;79:46e51.

Forza C. Survey research in operations management: a process-based perspective. Int Oper Prod Manage 2002;22(2):152-94.

Friedler E, Kovalio R, Gail NI. On-site grey water treatment and reuse in multi-storey buildings. Water Sci Technol 2005;51(10):187-94.

Ghisi E, Oliveira SM. Potential for potable water savings by combining the use of rainwater and grey water in houses in southern Brazil. Build Environ 2007:42(4):1731-42.

Gilg A, Barr S. Behavioural attitudes towards water saving? Evidence from a study of environmental actions. Ecol Econ 2006;57:400-14.

Gregory GD, Di Leo M. Repeated behaviour and environmental psychology: the role of personal involvement and habit formation in explaining water consumption. J Appl Soc Psychol 2003;33:1261-96.

Hadjikakou M, Chenoweth J, Miller G. Estimating the direct and indirect water use of tourism in the eastern Mediterranean. J Environ Manage 2013;114:548-56.

Hassell T, Cary J. Promoting behavioral change in household water consumption: literature review. Victoria: Smart Water; 2007.

Hoffmann M, Worthington A, Higgs H. Urban water demand with fixed volumetric charging in a large municipality: the case of Brisbane, Australia. Aust J Agric Resour Econ 2006;50(3):347-59.

Howarth D, Butler S. Communicating water conservation. How can the public be engaged? Water Supply 2004;4:33-4.

Inman D, Jeffrey P. A review of residential water conservation tool performance and influences on implementation effectiveness. Urban Water J 2006;3(3):127e143.

Jorgensen B, Graymore M, O'Toole K. Household water use behavior: an integrated model. J Environ Manage 2009;91:227-36.

Kenney D, Goemans C, Klein R, Lowrey J, Reidy K. Residential water demand management: lessons from Aurora, Colorado. J Am Water Resour Assoc 2008;44(1): $192 \mathrm{e} 207$.

Kim SH, Choi SH, Koo JK, Choi SI, Hyun IH. Trend analysis of domestic water consumption depending upon social, cultural, economic parameters. Water Sci Technol Water Supply 2007;7(5e6):61e68.

Loh M, Coghlan P. Domestic water use study. Perth: Water Corporation; 2003.

Lyman RA. Peak and off-peak residential water demand. Water Resour Res 1992;28: 2159 e2167.

Martínez-Espiñeira R. Estimating water demand under increasing-block tariffs using aggregate data and proportions of users per block. Environ Resour Econ 2003;26:5e23.

Matos C, Teixeira CA, Duarte AALS, Bentes I. Domestic water uses: characterization of daily cycles in the North Region of Portugal. Sci Total Environ 2013;458-460:444-50.

Mayer PW, DeOreo WB. Residential end uses of water. Boulder, CO: Aquacraft, Inc. Water Engineering and Management; 1999.

Melo-Batista J. A melhoria da eficiência do uso eficiente da água como contributo para a sustentabilidade dos recursos naturais 10 Encontro Nacional de Saneamento Básico: Uso sustentável da água: situação portuguesa e perspectivas de futuro; 2002.

Mondéjar-Jiménez JA, Cordente-Rodríguez M, Meseguer-Santamaría ML, Gázquez-Abad JC. Environmental behavior and water saving in Spanish housing. Int J Environ Res 2010;5(1):1-10. [ISSN: 1735-6865].

Murdock SH, Albrecht DE, Hamm RR, Backman K. Role of sociodemographic characteristics in projections of water use. J Water Resour Plann Manage 1991;117:235-51.

Nauges C, Thomas A. Privately operated water utilities, municipal price negotiation, and estimation of residential water demand: the case of France. Land Econ 2000;76(1): 68-85.

Niccolucci V, Botto S, Rugani B, Nicolardi V, Bastianoni S, Gaggi C. The real water consumption behind drinking water: the case of Italy. J Environ Manage 2011:92:2611-8.

Nunnally JC. Psychometric theory. 2nd ed. New York, NY: McGraw-Hill; 1978.

Renwick ME, Green RD. Do residential water demand side management policies measure up? An analysis of eight California water agencies. J Environ Econ Manage 2000;40: 37-55.

Reynaud A. An econometric estimation of industrial water demand in France. Environ Resour Econ 2003;25(2):213-32.

Shaw WD. Water resource economics and policy: an introduction. Cheltenham, UK: Northampton, MA, USA: E. Elgar; 2005.

Syme GJ, Nancarrow BE, Seligman C. The evaluation of information campaigns to promote voluntary household water conservation. Eval Rev 2000;24:539-78.

Tortella BD, Tirado D. Hotel water consumption at a seasonal mass tourist destination. The case of the island of Mallorca. J Environ Manage 2011;92:2568-79.

Willis RM, Stewart RA, Panuwatwanich K, Williams PR, Hollingsworth AL. Quantifying the influence of environmental and water conservation attitudes on household end use water consumption. J Environ Manage 2011a;92:1996-2009.

Willis RM, Stewart RA, Giurco DP, Talebpour MR, Mousavinejad A. End use water consumption in households: impact of socio-demographic factors and efficient devices. J Clean Prod 2011b. http://dx.doi.org/10.1016/j.jclepro.2011.08.006.

Willis RM, Stewart RA, Williams PR, Hacker CH, Emmonds SC, Capati G. Residential potable and recycled water end uses in a dual reticulated supply system. Desalination 2011c;272(1-3):201-11.

Worthington AC, Hoffman M. An empirical survey of urban water demand modelling. J Econ Surv 2008;22(5):842-71.

Zhang HH, Brown DF. Understanding urban residential water use in Beijing and Tianjin, China. Habitat Int 2005;29(3):469-91. 